\title{
Testing the Model of Human Resource Development Using (CFA)
}

\author{
Khaled Abdulla A. Etlesh ${ }^{1}$, Dr. Nasser Habtoor ${ }^{2}$ \\ ${ }^{1,2}$ Faculty of leadership and Management, Universiti Science Islamic Malaysia (USIM)
}

\begin{abstract}
The current study aimed to test the validity of a measurement model of the development of human resources from the perspective of employees in the National Oil Corporation in Libya. The measurement model consisted of human resource development as the latent factor that is represented by four dimensions (planning skill, communication skill, management skills and positive attitudes). To achieve this aim, we used a confirmatory factor analysis (Confirmatory Factor Analysis - CFA) through Amos. The results of the study indicated that this model is a valid measurement model that can be reliable for measuring the development of human resources.
\end{abstract}

Keywords: Planning Skill, Communication Skill, Management Skills, and Positive Attitudes

\section{Introduction}

The success of organizations in achieving their desired relies, to a large extent, on the performance of its human resources as well as their ability to adapt to the modern technology used in the work. This cannot be realized only through constant development of human resources as well environmental developments and changes. Therefore, continuous development of human resources is the foundation or basis upon which such organizations to reach their and achieve their goals. Thus, development of human resources has become one of the important and basic functions in the areas of business administration. This is because it is considered as an effective means to ensuring the achievement of the organization's goals and it enables organizations to become steady and able to face the current era changes, which has made organizations tend to invest in human resources.

Hence, human resource development is known as development of the skills and abilities of employees in a given organization. In other words, it refers to increasing the individuals' capacities and abilities to perform their assigned tasks more effectively. Human recourse development is also known as a way to raising employees' efficiency, providing them with the knowledge and raising their level of competence through acquiring capacity, creating a sense of belonging to the organizationamong them, authorizing and enriching the work and developing their decision-making (Hamdan, 2002). In addition, as stated by (Habib, 2005) in this direction, the most important things that are needed to be developed among employees in the organization are the attitudes. It means developing the individuals' willingness and tendencies related to their work. (Harem, 2004) defined attitudes as individuals' mental readiness through expertise and experience.

The planning process is one of the basic skills needed by human resources in the organization in the current era. It is defined as a set of administrative procedures, policies and systems of implementation needed by employees. Moreover, the process of communication is regarded as one of the important skills that must be mastered by employees in the organization. It is known as a set of communicational activities practiced by the organization during the different stages in the performance of the business. The leadership and its relevance skills are also the most important factors that should be provided among employees in the various administrative levels and that should be developed by them. Based on the foregoing definitions of human resource development including development of multiple skills, the current study attempted to develop a measurement model for development of human resources because such skills are considered as skills that must be provided on employees in order to raise their abilities and skills in performing the assigned work.

\section{Research Objectives}

The current study aimed to test the validity of a proposed model for measuring Human Resources Development in the National Oil Corporation, Libya.

\section{Method}

\section{The study population:}

The population of the current study is represented by employees National Oil Corporation in Libya. And due to the large size of the population, so the sample size was determined by $(10 \%)$ of the study population (Sekaran,2003), but the size of sample was (460). He distributed (460) questionnaires on the study sample; (383) questionnaires have been obtained where (77) thereof lost and (9) thereof excluded due to non-clear reply therein by the by the respondents. So the final number of questionnaires entered to the analysis was (374) questionnaire $(81 \%)$ of the total distributed questionnaire.

\section{Research Instruments}

In this regard, it is relied upon the questionnaire as a tool to gather the necessary information for this study as one of the most suitable scientific research tools that achieve the survey study objectives and to obtain information and facts associated with a determined reality, for achieving the study, a questionnaire is made for the purposes of processing the studying test the validity of a proposed model for measuring Human Resources Development. 


\section{International Journal of Science and Research (IJSR) \\ ISSN (Online): 2319-7064 \\ Index Copernicus Value (2013): 6.14 | Impact Factor (2015): 6.391}

Confirmatory Factor Analysis

The Structural Equation Modeling(AMOS) model-fitting program is used to test the validity constructs are to test the validity of a proposed model for measuring Human Resources Development. The overall model fit is assessed by using four indices of the model goodness-of-fit:(1) the comparative fit index (CFI)greater than $(0.90)$ (McDonald \& Marsh,1990);(2) the chi-square statistics;(3) the minimum value of the discrepancy between the observed data and thehypothesized model divided by degrees of freedom (CMIN/DF) or normed chi-square (Marsh \& Hocevar,1985)described that the minimum fit function for (CMIN/DF) of an acceptable fit is less than (5);(4) in addition (RMSEA) less than (0.08) (MacCallumet al, 1996).

\section{Construct Validity}

The employment of factor loading composite reliability (CR) and average variance extracted (AVE) were proposed by (Hair, et al,2006) to determine the convergent validity if it equals to or greater $\operatorname{than}(0.5) \quad(\geq 0.5)$ and the composite reliability equals to or greater than $(0.7)(\geq 0.7)$ if were recommended by (Hair et al,2006). In addition (AVE) reading values should be greater than $(0.5)(\geq 0.5)$ and greater than (Shared Variance-SV).
Development, it is evident that the model is free of the illogical correlation since it reaches or exceeds the integer (1). This also indicates that there is not any problems in the (CFA) used for testing the validity of this model that comprises four factors: The first factor including the Planning skill, the second factor including the Communication skill and the third factor containing the Leadership skill, the fourth factor containing thePositive Attitudes. As seen in Figure (1) and Table (1), the indicators of agreement between the model and the data exceeded the (T-value), thus, implying that there is disagreement between modelHuman Resources Development and the data of the sample since the value of the (Chi-Square) was (654.442) and the degree of freedom was (146), and the level of significance was $(\mathrm{P}=0.000)$. In addition, we can see that the normative (ChiSquare)(Chi-Square /degrees of freedom) was (4.482) less than (5), and the value of relative strength index (CFI) was (0.889) less than the (T-value) (0.90). The results also show that the value of the index (RMSEA) was (0.097) being higher than (0.080). Due to this contradiction between the model and the data, it was necessary to modify the Human Resources Developmentmodel in this study.

\section{Results}

The Modified Model

From Figure (1) that shows the results of the (CFA) for the proposed model for measuring Human Resources

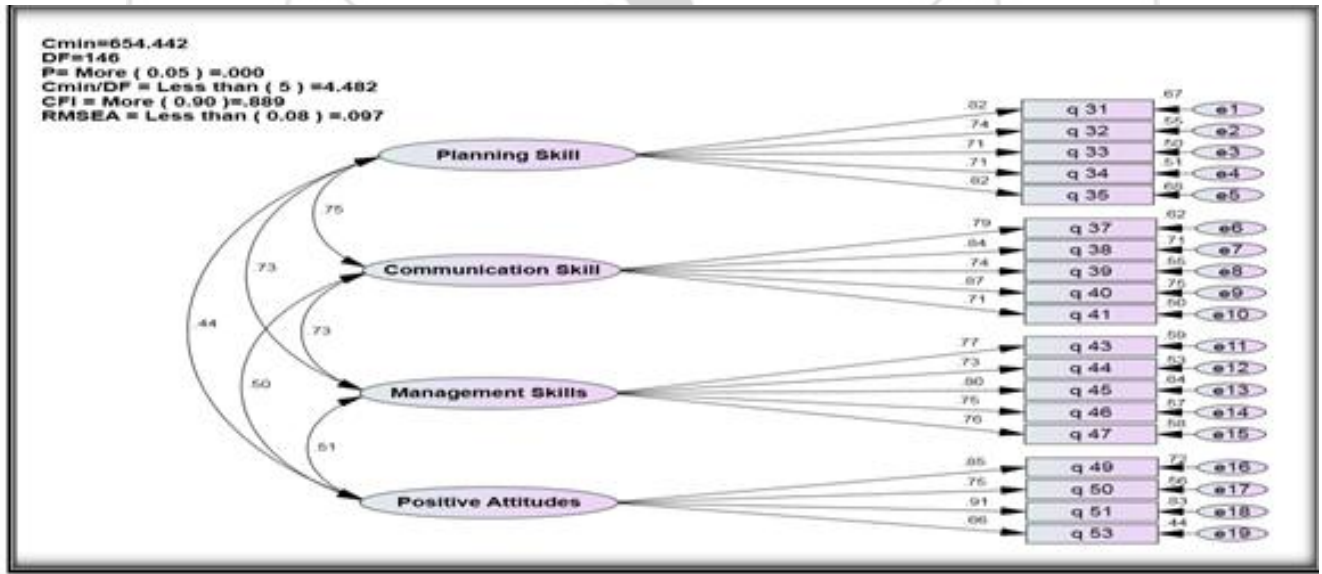

Figure 1: Model Human Resources Development before the amendment

In order to modify this model, we followed was deleting (q34, q41, q44). Because it was less loading of the other item at the same factor, in addition to linking item (q37) with item (q38) it was shown in Figure (2).

Table 1: index value of Human Resources Developmentmodel before and after modification

\begin{tabular}{|c|c|c|c|}
\hline indicators consistency & index value before modification & index value after modification & Function value on the quality of conformity \\
\hline CMIN & 654.442 & 215.793 & --- \\
\hline DF & 146 & 83 & Non \\
\hline P & 0.000 & 0.000 & Less than (5) \\
\hline CMIN /DF & 4.482 & 2.600 & More $(0.90)$ \\
\hline CFI & 0.889 & 0.962 & Less than $(0.08)$ \\
\hline RMSEA & 0.097 & 0.065 & \\
\hline
\end{tabular}

Confirmatory Factor Analysis of the Human Resources Development model:

The results of the goodness-of-fit of the final revised of the Human Resources Development model showed that normed chi- square (CMIN/DF) was (2.600), the (CFI) was (0.962) and (RMSEA)was (0.065). Figure (2) shows the adequacy of the final revised of the Human Resources Development model. 
International Journal of Science and Research (IJSR)

ISSN (Online): 2319-7064

Index Copernicus Value (2013): 6.14 | Impact Factor (2015): 6.391

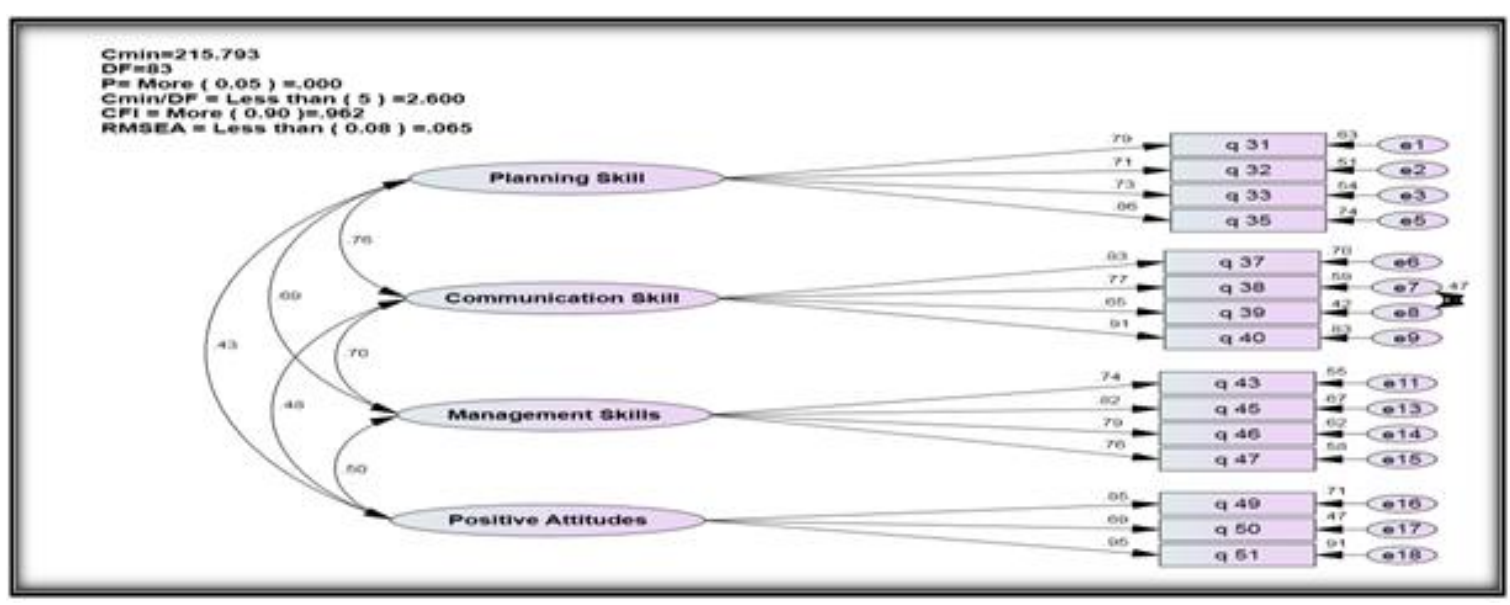

Figure 2: Model Human Resources Developmentafter amendment.

\section{Construct Validity and Reliability}

In this study, the factor lodging for the parameters ranged from $(0.65$ to 0.91$)$, with all parameters were above $(0.5)$ $(\geq 0.5)$. The reliability ranged from $(0.71$ to 0.89$)$, were greater than $(0.7)(\geq 0.7)$. Furthermore, the (AVE) readings was $(0.60,0.63,0.60,0.69)$ where the value was greater than
(0.5) $(\geq 0.5)$, all results fulfilled the (AVE), and The reliability discriminant validity of the model. Generally, the measurement model of the Human Resources Development model was fit and fulfilled the construct as depicted in table (2).

Table 2: Construct Validity and Reliability of Human Resources Development model

\begin{tabular}{|c|c|c|c|c|c|c|c|c|c|c|}
\hline No & Latent variables & Items & $\mathrm{R}$ & estimate & S. E & C. R & $\mathrm{P}$ & Loading & SMC & AVE \\
\hline q 31 & \multirow{4}{*}{ Planning Skill } & $\begin{array}{l}\text { Training has positive impact on the development of } \\
\text { planning skills }\end{array}$ & 0.81 & 0.90 & 0.051 & 17.545 & 0.000 & 0.79 & 0.63 & 0.60 \\
\hline q 32 & & $\begin{array}{l}\text { The management develops the skills related to } \\
\text { making procedures for preventing crises }\end{array}$ & 0.83 & 0.80 & 0.052 & 15.240 & 0.000 & 0.71 & 0.51 & - \\
\hline q 33 & & $\begin{array}{l}\text { The management develops the skills related to } \\
\text { auditing or reviewing and evaluating the plans on an } \\
\text { ongoing basis to avoid such crises }\end{array}$ & 0.83 & 0 & 0.052 & 15.787 & 0.000 & 0.73 & 0.54 & - \\
\hline q 35 & & $\begin{array}{l}\text { The management studies many scenarios and do } \\
\text { advance planning in dealing with crises as they } \\
\text { happen }\end{array}$ & 0.78 & 1.000 & - & - & - & 0.86 & 0.74 & - \\
\hline q 37 & \multirow{4}{*}{$\begin{array}{l}\text { Communication } \\
\text { Skill }\end{array}$} & $\begin{array}{l}\text { The management is interested in developing } \\
\text { employees' abilities to make speedy communication } \\
\text { appropriate to respond to crises }\end{array}$ & 0.86 & 0.96 & 0.045 & 21.000 & 0.000 & 0.83 & 0.70 & 0.63 \\
\hline q 38 & & $\begin{array}{l}\text { The management develops the skill related to } \\
\text { communicating with and contact the outside } \\
\text { community through the development of crisis } \\
\text { management operations }\end{array}$ & 0.83 & 0.79 & 0.043 & 18.406 & 0.000 & 0.77 & 0.59 & - \\
\hline q 39 & & $\begin{array}{l}\text { The organizational structure is flexible enough to } \\
\text { assist the cooperation and communication between } \\
\text { the different managements and departments }\end{array}$ & 0.87 & 0.69 & 0.049 & 14.118 & 0.000 & 0.65 & 0.42 & - \\
\hline $\mathrm{q} 40$ & & $\begin{array}{l}\text { The management provides a database of crisis } \\
\text { management }\end{array}$ & 0.82 & 1.000 & - & - & - & 0.91 & 0.83 & - \\
\hline q 43 & \multirow{4}{*}{ Management Skills } & $\begin{array}{l}\text { The management trains human resources on problem- } \\
\text { solving skills within and outside the organization }\end{array}$ & 0.83 & 0.85 & 0.056 & 15.079 & 0.000 & 0.74 & 0.55 & 0.60 \\
\hline q 45 & & $\begin{array}{l}\text { The leader has the skills and personal traits that } \\
\text { qualify him to control crisis }\end{array}$ & 0.79 & 1.000 & - & - & - & 0.82 & 0.67 & - \\
\hline q 46 & & $\begin{array}{l}\text { The management trains the staff on decision-making } \\
\text { skills in emergency situations and crises }\end{array}$ & 0.82 & 0.94 & 0.058 & 16.236 & 0.000 & 0.79 & 0.62 & - \\
\hline q 47 & & $\begin{array}{l}\text { The management trains human resources on skills } \\
\text { related to motivating employees and raising their } \\
\text { spirits at the time of crisis }\end{array}$ & 0.82 & 0.94 & 0.058 & 15.686 & 0.000 & 0.76 & 0.58 & - \\
\hline q 49 & \multirow{3}{*}{ Positive Attitudes } & $\begin{array}{l}\text { I feel satisfied about the training courses in dealing } \\
\text { with crises that I have attended }\end{array}$ & 0.79 & 0.91 & 0.044 & 20.504 & 0.000 & 0.85 & 0.71 & 0.69 \\
\hline q 50 & & $\begin{array}{l}\text { I have the desire and willingness to learn from the } \\
\text { past crises }\end{array}$ & 0.89 & 0.72 & 0.047 & 15.358 & 0.000 & 0.69 & 0.47 & - \\
\hline q 51 & & $\begin{array}{l}\text { I feel I have acquired the attitudes that enable me to } \\
\text { perform efficiently in the event of crises }\end{array}$ & 0.71 & 1.000 & - & - & - & 0.71 & 0.51 & - \\
\hline
\end{tabular}

S.E. Standard Error, C.R: Critical Ratio, P: Probability, SMC: Squared Multiple Correlation, AVE: Average Variance Extracted, R: Reliability. 


\section{Conclusion}

The present study aimed to test the validity of the developed measurement model for measuring human resource development. The model included human resource development as the latent variable that is represented by four factors (planning skill, the skill of communication, management skills and positive attitudes). In order to achieve this research aim, which is testing the validity of this model for measuring human resource development, the study used a (Confirmatory Factor Analysis - CFA) through (Amos,21). Based on the results of the analysis obtained from the use of (Amos) shown in Figure (1) and Table (1), there is a contradiction between the developed model and the data. This emphasizes the need to modify the model, and after the process of modifications illustrated in Figure (2) and Table (2), there is a goodness of fit between the model and the data. This is evidenced by the congruence indicators, as the average variation extracted value (Average Variance Extracted -AVE) for all factors was higher than (0.50) and even higher than (Shared Variance-SV).Therefore, the measurement model is characterized by the congruent validity and convergent validity. This means that the proposed measurement model is valid to be used for measuring human resource development.

\section{References}

[1] Hair, J. F., Anderson, R. E., Tatham, R. L. \& Black, W. C. (2006). Multivariate Data Analysis (5th ed.), New Jersey, Prentice-Hall.

[2] Hamdan, Soraya Hassan (2002). Management excellence and how to acquire the basic skills. Al Ahram Agency for Publishing and Distributing. Egypt, Cairo.

[3] Harim, Hussein (2004). Organizational behavior. Dar AlHamed for Publication and Distribution. Cairo.

[4] MacCallum, R. C., Browne, M. W., \& Sugawara, H. M. (1996). Power Analysis and Determination of Sample

[5] Marsh, H. W., \& Hocevar, D. (1985). Application of confirmatory factor analysis to the study of self-concept: First-and higher order factor models and their invariance across groups. "Psychological bulletin", 97(3), 562-582. http://dx.doi.org/10.1037/0033-2909.97.3.562

[6] McDonald, R. P., \& Marsh, H. W. (1990). Choosing a multivariate model: Noncentrality and goodness of fit. "Psychological Bulletin", 107(2), 247-255.

[7] Mohammed, Mannar, Al-Habib (2005). The effect of human resource development on the preparation for crises. An Empirical Study on the Ain Shams University Hospitals. Master Thesis. Commerce College. Ain-Shams University.

[8] Sekaran, U. (2003). Research Methods for Business: A Skill Buiding Approach (4 ${ }^{\text {th }}$ Ed). New York: Wiley. SILVERMAN, D.2000.Doing Qualitative Research. 